\title{
Ketogenic diet reduces Lafora bodies in murine Lafora disease
}

Lori Israelian, MSc, Peixiang Wang, PhD, Shoghig Gabrielian, BSc, Xiaochu Zhao, BSc, and Berge A. Minassian, MD

Neurol Genet 2020;6:e533. doi:10.1212/NXG.0000000000000533

\author{
Correspondence \\ Dr. Minassian \\ berge.minassian@ \\ utsouthwestern.edu
}

Lafora disease $(\mathrm{LD})$ is a teenage-onset fatal progressive myoclonus epilepsy caused by loss-offunction mutations in the EPM $2 A$ gene encoding the glycogen phosphatase laforin or EPM2B encoding the laforin-interacting ubiquitin E3 ligase malin. Concerted actions of glycogen synthase (GS) and branching enzyme generate normal short-branched soluble glycogen. In LD, some glycogen molecules develop long branches, precipitate, and accumulate into pathognomonic and pathogenic Lafora bodies (LBs). The precise mechanism by which the laforin-malin complex mitigates this is unknown, but thought to involve GS downregulation. In fact, transgenic GS downregulation in LD mouse models reduces LB formation and rescues the disease. $^{1,2}$

The ketogenic diet is potently antiepileptic in part through keto acid generation and related bacterial cross-feeding leading to $\gamma$-glutamyl transpeptidase and $\gamma$-glutamylation inhibition. ${ }^{3}$ Patients on the diet maintain blood glucose levels in the low-normal range, and the brain relies more heavily on keto acids. We hypothesized that the reduced glucose availability in the brain might reduce glycogen synthesis sufficiently to reduce LB formation in LD, which we tested in the Epm $2 a^{-/-}$model of the disease.

Our work was approved by The Centre for Phenogenomics Animal Care Com 1 mittee (Toronto). From weaning, Epm2 $a^{-/-}$mice were fed a ketogenic diet (Teklad TD.96355: $9.2,0.5$, and $90 \%$ kcals from protein, carbohydrate, and fat respectively) or normal chow ad libitum. Blood ketone ( $\beta$-hydroxybutyrate) and glucose levels were measured through tail venipuncture using the Nova Max Plus system. Mice were killed at 7 months by cervical dislocation. For glycogen measurement, rapidly frozen brain, or quadriceps muscle, were ground in liquid nitrogen and boiled in $30 \% \mathrm{KOH}$. Glycogen was precipitated thrice in $67 \% \mathrm{EtOH} / 15 \mathrm{mM} \mathrm{LiCl}$ and digested with amyloglucosidase $\left(55^{\circ} \mathrm{C}, 1\right.$ hour, $80 \mathrm{mM}$ $\mathrm{NaOAc}, \mathrm{pH} 4.5$ ) to glucose, which was quantified enzymatically. ${ }^{4}$ For Western blotting, the brain was homogenized using $18 \mathrm{G} \times 1 \frac{1}{1 / 2}$ BD PrecisionGlide needles in ice cold buffer (see also e-Methods, links.lww.com/NXG/A337). For histopathology, formalin-fixed paraffin-embedded brain sections were stained with periodic acid-Schiff following diastase predigestion, which labels LBs. The HistoQuant module of 3DHISTECH was used to detect (based on hue, saturation, and color) and measure the percent LBs of total hippocampal area.

Ketogenic diet-fed mice maintained low-normal blood glucose and ketosis throughout the study (figure, A and B). At sacrifice, they had, respectively, 22 and 23\% reduced LBs and brain glycogen (at this age, the large majority of brain glycogen is $\mathrm{LBs}^{1}$ ) (figure, $\mathrm{C}$ and $\mathrm{D}$ and figure e-1, links.lww.com/NXG/A337). Skeletal muscle glycogen, where again at this age LBs predominate, was reduced by greater than $50 \%$ (figure, E). 
Figure Blood $\beta$-hydroxybutyrate and glucose, hippocampal LB, total brain glycogen, total skeletal muscle glycogen, and brain phosphorylated GS levels in LD mice fed the ketogenic diet or normal chow

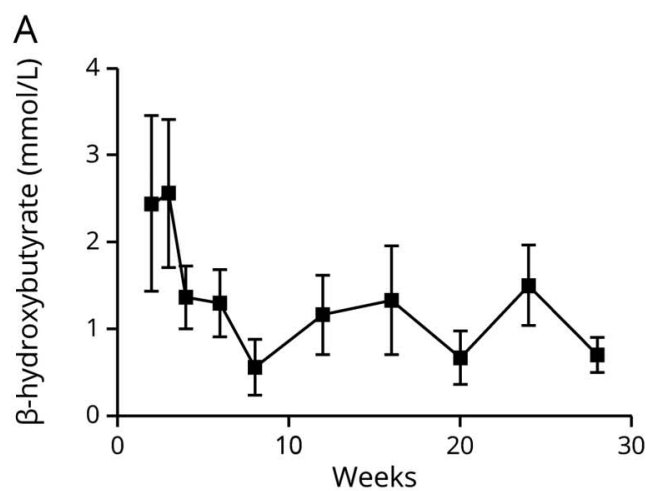

C

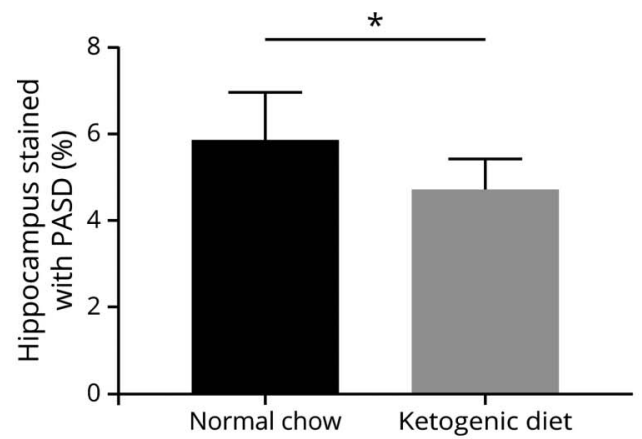

E

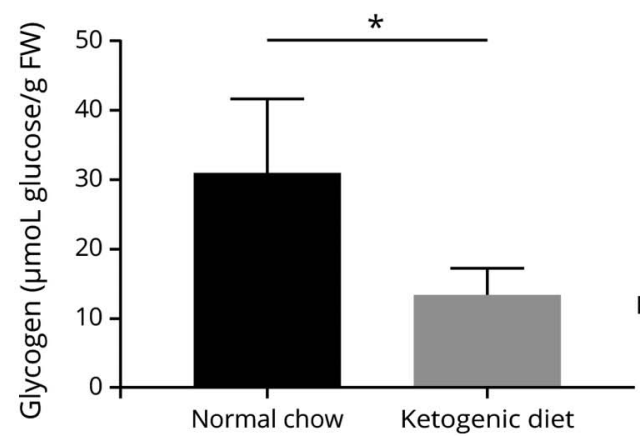

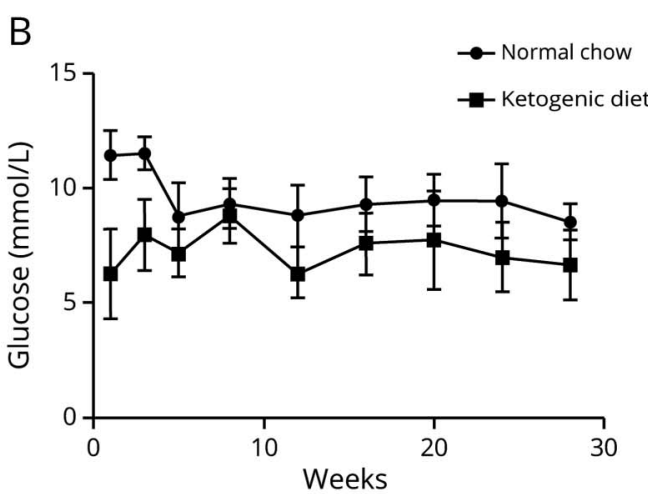

D

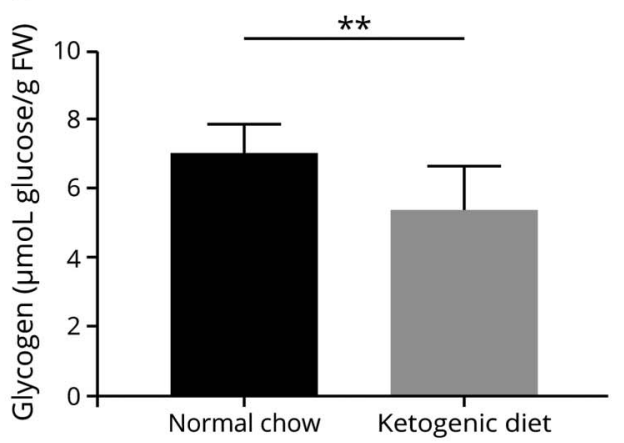

F

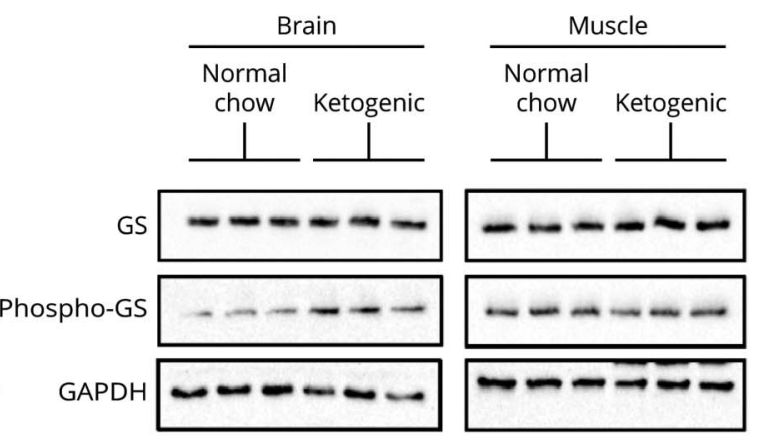

(A) Blood $\beta$-hydroxybutyrate; time course begins 2 weeks following initiation of diet and concludes at 28 weeks; 6 mice per week. (B) Blood glucose; beginning at 1 week of diet introduction and concludes at 28 weeks; 5-8 mice per week. (C) Hippocampal LBs; 8-9 mice per group. (D) Total brain glycogen; 8-10 mice per group. (E) Skeletal muscle glycogen; 4 mice per group. Bars in A-E represent SD of the mean. Significance for all bar diagrams calculated using the unpaired Student $t$ test: $* p<0.05 ; * *<0.01$. (F) Brain GS phosphorylation (inhibition) is increased in ketogenic diet-fed animals; 3 biological replicates per diet type. FW = fresh weight; GAPDH = glyceraldehyde 3-phosphate dehydrogenase; GS = glycogen synthase; LB = Lafora body; LD = Lafora disease; PASD = periodic acid-Schiff following diastase predigestion.

GS is inactivated through hierarchical phosphorylation culminating in phosphorylation at serine $641 .{ }^{5}$ Western blotting brain extracts with a specific antibody showed that this site was hyperphosphorylated in ketogenic diet-fed mice (figure, $\mathrm{F})$, indicating relative GS inactivation.

The ketogenic diet has been studied in human LD, but only as a pilot in 5 patients with the diet initiated years after onset, i.e., well into the disease's neurodegenerative course. The authors did not detect clinical improvement. However, they noted a large variability in disease course and concluded that "...further studies...should include a larger number of treated patients, making provision for subgroup stratification...." In fact, their patient with mildest disease at treatment initiation remained cognitively "... substantially stable for 16 months..." and thereafter progressed unusually slowly. ${ }^{6}$

LD mice have normal lifespans and their behavioral and epileptic abnormalities are subtle. These can be measured, but only at advanced age ( $\sim 12$ months). Their correction has also been measured, but with GS knockout or knockdown approaches that achieved $\sim 80 \%$ LB reduction. ${ }^{1,2}$ The 22\% LB reduction with the ketogenic diet is therefore 
modest, but not insignificant. It is, incidentally, similar to the effect on LBs by metformin, ${ }^{7}$ which also acts in part through GS inhibition. Given the clear relationship between LBs and the neurologic disease, any LB reduction is likely protective.

The ketogenic diet reduces brain glucose supply. Glucose would therefore channel toward consumption vs storage, to which end GS would be expected to be inactivated, which we demonstrate.

Work is underway to develop drugs (antisense oligonucleotides and small molecules) aimed at reducing GS activity as a potential treatment for $\mathrm{LD} .{ }^{1}$ Meanwhile, the ketogenic diet is an existing therapy. LD is presently diagnosed much more rapidly than in years past, its genes (EPM2A and EPM2B) now included in essentially all epilepsy gene panels. The present preclinical work suggests initiation of the diet at diagnosis, preferably through an internationally organized study including adequate numbers of yet minimally affected patients. This will likely benefit, and at least clarify, the particular role of the diet in patients with this particularly catastrophic epilepsy.

\section{Study funding}

This work was funded by the NIH under award P01NS097197. B.A. Minassian holds the University of Texas Southwestern Jimmy Elizabeth Westcott Chair in Pediatric Neurology.

\section{Disclosure}

The authors report no disclosures. Go to Neurology.org/NG for full disclosures.

\section{Publication history}

Received by Neurology: Genetics July 16, 2020. Accepted in final form September 28, 2020.

\begin{tabular}{|c|c|c|}
\hline Name & Location & Contribution \\
\hline $\begin{array}{l}\text { Lori } \\
\text { Israelian, } \\
\text { MSc }\end{array}$ & $\begin{array}{l}\text { The Hospital for Sick } \\
\text { Children, Toronto, ON, } \\
\text { Canada }\end{array}$ & $\begin{array}{l}\text { Designed and conceptualized } \\
\text { the study; major role in data } \\
\text { acquisition; analyzed the } \\
\text { data; and drafted the } \\
\text { manuscript for intellectual } \\
\text { content }\end{array}$ \\
\hline $\begin{array}{l}\text { Peixiang } \\
\text { Wang, PhD }\end{array}$ & $\begin{array}{l}\text { The Hospital for Sick } \\
\text { Children, Toronto, ON, } \\
\text { Canada }\end{array}$ & $\begin{array}{l}\text { Major role in data } \\
\text { acquisition and analyzed } \\
\text { the data }\end{array}$ \\
\hline $\begin{array}{l}\text { Shoghig } \\
\text { Gabrielian, } \\
\text { BSc }\end{array}$ & $\begin{array}{l}\text { The Hospital for Sick } \\
\text { Children, Toronto, ON, } \\
\text { Canada }\end{array}$ & $\begin{array}{l}\text { Major role in data } \\
\text { acquisition }\end{array}$ \\
\hline $\begin{array}{l}\text { Xiaochu } \\
\text { Zhao, BSc }\end{array}$ & $\begin{array}{l}\text { The Hospital for Sick } \\
\text { Children, Toronto, ON, } \\
\text { Canada }\end{array}$ & $\begin{array}{l}\text { Major role in data } \\
\text { acquisition }\end{array}$ \\
\hline $\begin{array}{l}\text { Berge A. } \\
\text { Minassian, } \\
\text { MD }\end{array}$ & $\begin{array}{l}\text { The Hospital for Sick } \\
\text { Children, Toronto, ON, } \\
\text { Canada and University of } \\
\text { Texas Southwestern, Dallas }\end{array}$ & $\begin{array}{l}\text { Designed and } \\
\text { conceptualized the study; } \\
\text { oversaw the project; } \\
\text { analyzed the data; and } \\
\text { drafted the manuscript for } \\
\text { intellectual content }\end{array}$ \\
\hline
\end{tabular}

\section{References}

1. Nitschke F, Ahonen SJ, Nitschke S, Mitra S, Minassian BA. Lafora disease: from pathogenesis to treatment strategies. Nat Rev Neurol 2018;14:606-617.

2. Duran J, Gruart A, Garcia-Rocha M, et al. Glycogen accumulation underlies neurodegeneration and autophagy impairment in Lafora disease. Hum Mol Genet 2014;23: 3147-3156.

3. Olson CA, Vuong HE, Yano JM, Liang QY, Nusbaum DJ, Hsiao EY. The gut microbiota mediates the anti-seizure effects of the ketogenic diet. Cell 2018;173:1728-1741.

4. Sullivan MA, Nitschke S, Skwara EP, et al. Skeletal muscle glycogen chain length correlates with insolubility in mouse models of polyglucosan-associated neurodegenerative diseases. Cell rep 2019;27:1334-1344.e6.

5. Roach PJ, Skurat AV, Harris RA. Regulation of glycogen metabolism. In: Jefferson LS, Cherrington AD, editors. Handbook of Physiology. Section 7, Vol. II. The Endocrine Pancreas and Regulation of Metabolism. New York: Oxford University Press; 2001: 609-647.

6. Cardinali S, Canafoglia L, Bertoli S, et al. A pilot study of a ketogenic diet in patients with Lafora body disease. Epilepsy Res 2006;69:129-134.

7. Berthier A, Payá M, García-Cabrero AM, et al. Pharmacological interventions to ameliorate neuropathological symptoms in a mouse model of Lafora disease. Mol Neurobiol 2016;53:1296-1309. 


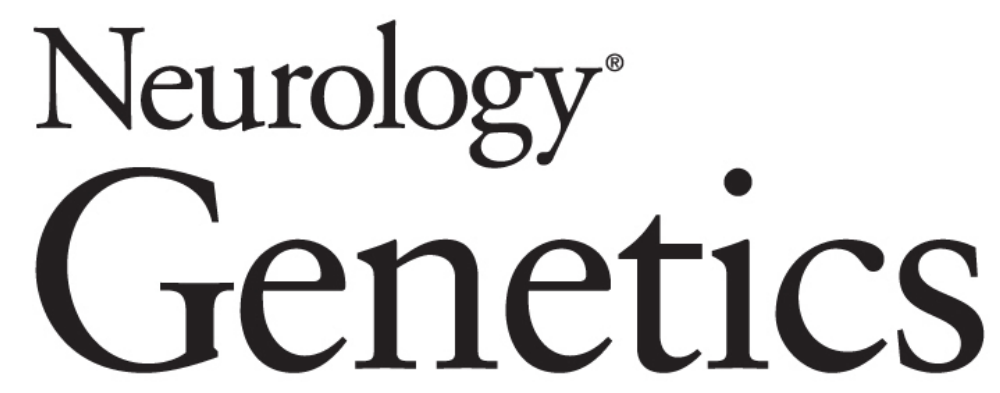

Ketogenic diet reduces Lafora bodies in murine Lafora disease Lori Israelian, Peixiang Wang, Shoghig Gabrielian, et al. Neurol Genet 2020;6;

DOI 10.1212/NXG.0000000000000533

This information is current as of November 19, 2020

$\begin{array}{ll}\begin{array}{l}\text { Updated Information \& } \\ \text { Services }\end{array} & \begin{array}{l}\text { including high resolution figures, can be found at: } \\ \text { http://ng.neurology.org/content/6/6/e533.full.html }\end{array} \\ \text { References } & \begin{array}{l}\text { This article cites } 6 \text { articles, } 0 \text { of which you can access for } \\ \text { http://ng.neurology.org/content/6/6/e533.full.html\#\#ref-lis- }\end{array} \\ \text { Permissions \& Licensing } & \begin{array}{l}\text { Information about reproducing this article in parts (figures, } \\ \text { its entirety can be found online at: } \\ \text { http://ng.neurology.org/misc/about.xhtml\#permissions }\end{array} \\ \text { Reprints } & \begin{array}{l}\text { Information about ordering reprints can be found online: } \\ \text { http://ng.neurology.org/misc/addir.xhtml\#reprintsus }\end{array}\end{array}$

Neurol Genet is an official journal of the American Academy of Neurology. Published since April 2015, it is an open-access, online-only, continuous publication journal. Copyright Copyright ( 2020 The Author(s). Published by Wolters Kluwer Health, Inc. on behalf of the American Academy of Neurology.. All rights reserved. Online ISSN: 2376-7839.

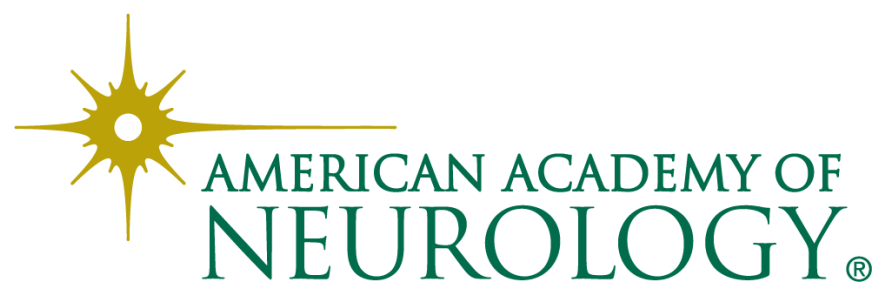

